\title{
Deciphering Role of Gut Micro-biome of Earthworms in Bio-remediation Process using Metagenome
}

\author{
Shweta Yadav ${ }^{1}$
}

${ }^{1}$ Department of Zoology, Dr H S Gour Central Vishwavidalaya (A Central University), Sagar -470003, MP, India

\begin{abstract}
Over the past few centuries the human activities for exploration of natural resources had a negative impact on the global balance including soil ecosystem. Nature has its ways of resolving imbalances in the environment and organisms are one of the best tools of nature to eliminate toxic pollutants. The biological process of eliminating pollutants (bioremediation) with activities of earthworms and associated gut micro-biome may translate to improve bioremediation process and to improve soil health. Present study focused to decipher role of gut microbes of earthworms using metagenomic approach.
\end{abstract}

\section{Introduction}

Earthworms (Annelida: Oligochaeta) ranges in size from 2 centimeters to over 2 meters, and occur in habitats ranging from boreal to tropical, sea level to 5000 meters elevation, semi-arid to extremely humid, aerobic to nearly anoxic and even aquatic. Some are predatory but greater majority feed on forms of organic matter in or above soil. They have potential to bioremediate soils by reducing the pollutants concentration through a bioaccumulation mechanism (Gupta et al.,2015). Earthworms occupy major invertebrate biomass $(>80 \%)$ in terrestrial ecosystem and have over 600 million years of experience as environmental managers in the ecosystem as 'waste managers' as 'soil managers', 'fertility improvers' and 'plant growth promoters' for long time (Sinha et al., 2010). New discoveries about their role in bioremediation of industrial wastes, chemically contaminated soil, dairy industry waste material, and detergent industries have revolutionized the understanding for functioning of this animal (Sturzenbaum et al.,2004). Earthworm can uptake and accumulate metals such as cadmium, mercury in their tissues when living both in non-contaminated and contaminated environments and released into less toxic forms (Gupta et al.,2014). Chemical changes in alimentary tract of earthworms may render various metals more available to plants, and mineralization of dead earthworms' releases metals-accumulated, metals in the environment. They have also been reported to host microbes in their gut which can biodegrade chemicals (Edwards and Bohlen, 1996). Within the soil environment, an earthworm's sphere of influence is known as the "drilosphere system" which incorporates the burrow systems; surface and below-ground earthworm casts, internal earthworm gut and process, the earthworm surface in contact with the soil, and associated biological, chemical and physical interactions, in addition to soil microorganisms. The micro-biota of earthworm is still not explored completely. The entire communities of their gut associated microbes (with bypassing to isolate and culture individual microbial species) may be explored by using metagenomics approach to improve our understanding of bioremediation process.

\subsection{Materials and Methods}

3.1 Collection of earthworms

Different sps. of earthworms (Eisenia foetida,Perionyx sansibaricus, Eudrilus eugeniae,Lennogaster pusillus) were collected from vermibed seeded with different feed materials (Table1,cow dung, leaf litter, kitchen waste) from Sagar-MP, India (Latitude $23^{0} 50^{\prime} 2^{\prime \prime} \mathrm{N}$; Longitude $78^{0} 47^{\prime} 1^{\prime \prime} \mathrm{E}$; 550m elevation) during January, 2016. For identification, collected specimens were preserved in ethyl alcohol for molecular characterization, and also fixed in $4 \%$ formalin for morpho-anatomical study.

This article is published under the terms of the Creative Commons Attribution License 4.0 Author(s) retain the copyright of this article. Publication rights with Alkhaer Publications. Published at: http://www.ijsciences.com/pub/issue/2016-04/

DOI: 10.18483/ijSci.1002; Online ISSN: 2305-3925; Print ISSN: 2410-4477 
The Use of Geoinformtics in Site Selection for Suitable Landfill for Poultry Waste: A Case Study of Amo Farms, AWE AFIJIO, Oyo State

Table 1.Details of samples studied for metagenome analysis

\begin{tabular}{|l|l|}
\hline Sample no & Earthworm sps. \\
\hline T-1. & Eisenia foetida (control) \\
\hline T-2. & Eisenia foetida (cow dung) \\
\hline T-3 & Eisenia foetida (leaf litter) \\
\hline T-4. & Eisenia foetida (kitchen waste) \\
\hline T-5. & Perionyx sansibaricus (control) \\
\hline T-6. & Perionyx sansibaricus (cow dung) \\
\hline T-7. & Perionyx sansibaricus ( leaf litter) \\
\hline T-8. & Perionyx sansibaricus (kitchen waste) \\
\hline T-9. & Eudrilus eugeniae (control) \\
\hline T-10. & Eudrilus eugeniae(in cow dung) \\
\hline T-11. & Eudrilus eugeniae( in leaf litter) \\
\hline T-12. & Eudrilus eugeniae (kitchen waste) \\
\hline T-13. & Lennogaster pusillus (control) \\
\hline T-14. & Lennogaster pusillus (cow dung) \\
\hline
\end{tabular}

\subsection{Characterization of earthworms}

Collected earthworms were identified with the help of available literature (Gates, 1972); later reconfirmed with amplified 683 bp cytochrome oxidase coi-I gene. The universal primers, LCO1490 (5। GGTCAACAAATCATAAAGATATTGG-3') and $\mathrm{HCO} 2198$

TAAACTTCAGGGTGACCAAAAAATCA-3')

(Folmer et al., 1994) were used to amplify coi-I gene sequences. Master mix used for PCR reactions contained $1 \mathrm{U}$ Taq polymerase (JonakiTaq, CCMB, Hyderabad, India), $1.5 \mathrm{mM} \mathrm{MgCl}_{2}, 0.2 \mathrm{mM}$ of each primer, $0.125 \mathrm{mM}$ of each deoxynucleotide. Thermal cycling was done in the ABI thermocycler with following conditions of PCR; $4 \mathrm{~min}$ initial denaturation at $94^{\circ} \mathrm{C}, 33$ cycles of 1 min denaturation at $94^{\circ} \mathrm{C}, 1 \mathrm{~min}$ annealing at $45^{\circ} \mathrm{C}, 1 \mathrm{~min}$ elongation at $72^{\circ} \mathrm{C}$, and a final elongation at $72^{\circ} \mathrm{C}$ for $10 \mathrm{~min}$ followed by $4{ }^{\circ} \mathrm{C}$ for $10 \mathrm{~min}$. The PCR products were visualized on $1.0 \%$ agarose gels with $1 \mathrm{X}$ TAE buffer and $0.5 \mu \mathrm{g} / \mathrm{mL}$ EtBr. The PCR products of the expected size were purified using the QIAquick Gel Purification Kit (QIAGEN GmbH, Hilden, Germany) following the manufacturers' protocols. Purified PCR products were sequenced using BigDye Terminator Cycle Sequencing Kit (Applied Biosystems, Foster City, California) on an ABI3500 with LCO 1490 HCO2198 primers (Xcelris Genomics Pvt. Ltd., Ahmedabad, India). The electropherograms were processed and analyzed with Bio-edit (http://www.mbio.ncsu.edu/bioedit/bioedit.html) and phylogenetic analyses was conducted using MEGA v6.

\subsection{Collection of samples}

Collected worms were thoroughly washed in running tap water before rinsing in distilled water. Worms were placed on wet cotton to ensure complete defecation in order to avoid contamination and their gut swab were collected in cryovials. These vials were then immediately frozen into liquid nitrogen.3.4 DNA extraction

DNA was extracted using QIAamp DNA extraction kit (Qiagen,USA) and metagenomes was quantified using the Qubit spectrophotometer .

\subsection{Amplicon Sequencing}

16S rRNA amplicon Sequencing on Illumina MiSeq Platform was used at Xcelris Genomics Pvt. Ltd., Ahmedabad, India. The V3-V4 (Product size 459bp) region of extracted 16s RNA PCR amplified product was reamplified using specific V3-F and V4-R primers with overhang adapter via PCR. Afterwards, PCR products was purified by using AmPure XP beads and checked on DNA-1000 chip on Agilent Bioanlyzer 2100, and also by running in $1.5 \%$ agarose gel. The purified amplicons were undergone Indexing PCR with Nextera XT Indices. And, resulting Index PCR products was purified using AmPure XP beads and run on DNA- 1000 chip on Agilent Bioanlyzer 2100. Libraries was quantified using Qubit HS and qPCR. The pooled PCR products (library) was loaded on MiSeq for cluster generation by hybridization of onto the oligonucleotide-coated surface of the flowcell. Immobilized DNA template copies was amplified by bridge amplification to generate clonal DNA clusters. The kit reagents was used for binding samples to complementary adapter oligos on paired-end flowcell. MiSeq Reagent Kit was used for sequencing metagenome library (2×300bp; PE) on Illumina MiSeq platform.

\subsection{Data Analysis:}

QIIME was used for 16S/ITS2 for the assignment of taxonomic data using a naive bayesian classifier.

\subsection{Results and Discussions}

In general, the taxonomy abundance in different earthworm sps reared on various feed materials was 
The Use of Geoinformtics in Site Selection for Suitable Landfill for Poultry Waste: A Case Study of Amo Farms, AWE AFIJIO, Oyo State

reported $65.7 \%$ Firmcutes; $18 \%$ Bacteroidetes; 7.63 $\%$ Spirochaetes; $3.17 \%$ Proteobacteria; $2.05 \%$ Actinobacteria; 1.64 \%unassigned. Fig 1.followed with table depicts details of micro-biomes in different sps of worms. The data explicit micro-biomes of gut of earthworm were species and reactors dependent.

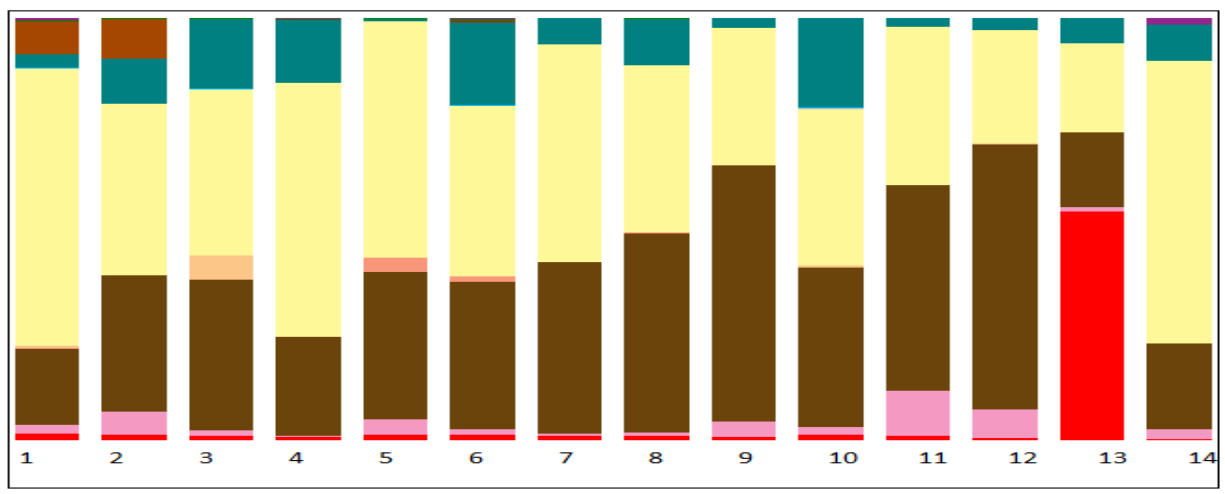

Fig 1.Comparative Analysis, QIIME level-2 OTU classifications (phylum level) between all samples followed by table.

\begin{tabular}{|c|c|c|c|c|c|c|}
\hline $\begin{array}{l}\text { Sample } \\
\text { no }\end{array}$ & Firmi-cutes & Bactero-idetes & $\begin{array}{l}\text { Spiroch- } \\
\text { aetes }\end{array}$ & $\begin{array}{l}\text { Proteo- } \\
\text { bacterisa }\end{array}$ & Actino-bacteria & Un-assigned \\
\hline \multicolumn{7}{|l|}{ Legand } \\
\hline $\mathrm{T}-1$ & $64.60 \%$ & $19.00 \%$ & $7.80 \%$ & $3.10 \%$ & $2.20 \%$ & $1.80 \%$ \\
\hline $\mathrm{T}-2$. & $45.60 \%$ & $31.30 \%$ & $9.50 \%$ & $11.50 \%$ & $5.90 \%$ & $1.40 \%$ \\
\hline $\mathrm{T}-3$ & $40.30 \%$ & $32.60 \%$ & $0.00 \%$ & $17.60 \%$ & $9 \%$ & $1.40 \%$ \\
\hline $\mathrm{T}-4$. & $62.10 \%$ & $21.40 \%$ & $0.00 \%$ & $15.90 \%$ & $0.40 \%$ & $0.40 \%$ \\
\hline $\mathrm{T}-5$. & $54.90 \%$ & $34.00 \%$ & $0.00 \%$ & $0.60 \%$ & $2.60 \%$ & $1.30 \%$ \\
\hline T-6. & $42.60 \%$ & $32.90 \%$ & $0.00 \%$ & $18.60 \%$ & $1.30 \%$ & $1.30 \%$ \\
\hline $\mathrm{T}-7$. & $52.50 \%$ & $41.70 \%$ & $0.00 \%$ & $5.20 \%$ & $0.50 \%$ & $1.20 \%$ \\
\hline $\mathrm{T}-8$. & $49.70 \%$ & $46.10 \%$ & $0.00 \%$ & $13.00 \%$ & $0.90 \%$ & $1.30 \%$ \\
\hline $\mathrm{T}-9$. & $34.60 \%$ & $61.60 \%$ & $0.00 \%$ & $2.10 \%$ & $2.80 \%$ & $0.80 \%$ \\
\hline $\mathrm{T}-10$. & $37.00 \%$ & $38.70 \%$ & $0.00 \%$ & $22.20 \%$ & $1.70 \%$ & $1.20 \%$ \\
\hline $\mathrm{T}-11$. & $38.50 \%$ & $47.60 \%$ & $0.00 \%$ & $2.00 \%$ & $11.90 \%$ & $0.90 \%$ \\
\hline $\mathrm{T}-12$. & $27.80 \%$ & $63.70 \%$ & $0.00 \%$ & $2.80 \%$ & $7.80 \%$ & $0.70 \%$ \\
\hline $\mathrm{T}-13$. & $22.10 \%$ & $18.50 \%$ & $0.00 \%$ & $5.70 \%$ & $1.20 \%$ & $56.10 \%$ \\
\hline $\mathrm{T}-14$. & $65.70 \%$ & $20.30 \%$ & $0.00 \%$ & $8.90 \%$ & $2.30 \%$ & $0.40 \%$ \\
\hline
\end{tabular}

It can be concluded that symbiotic organisms and parasites in different species of earthworms may be a driving force degradation process and, therefore, essential for their surviving. The symbionts, pathogens, and parasite, might contribute to: 1) the death of the host ; 2) a facilitated food digestion. For example, specialized bacteria inhabiting intestine and intestinal caeca, produce cellulose and ligninase facilitating the digestion of wood in the $\log$ inhabiting South-American genus Martiodrilus (Oligochaeta: Glossoscolecidae) ; 3) an immunity boost (Jinek et al. 2012) that allow earthworms to live in the "hostile environments" full of the pathogenic micro-organisms. For example, the immunity boost allows earthworms survival in the manure (e.g. Eisenia fetida) and compost heaps (e.g. Dendrobaena veneta) and inhabiting polluted waters

\section{(e.g. Eiseniella tatraedra).}

Activities of earthworms sps. and associated gut micro-biome can translate to soil and water bioremediation. Certain epigeic, and usually widely spread, species of earthworms (Eisenia fetida, Aporrectodea tuberculata, Lumbricus terrestris, $L$. rubellus, Dendrobaena rubida, D. veneta, Eiseniella tetraedra, Allobophora chlorotica) in general are highly resistant to many chemical contaminants including heavy metals, organic pollutants, nanoparticles in soil and remove wide range of chemicals from soils. They have been reported to bioaccumulate them in their tissues and either biodegrade or bio-transform them to harmless products with the aid of enzymes. Theoretically, the resistance against bacterial and viral infection can 
transform earthworms to source antibiotics, anti-viral drugs and other molecules in human medicine. An example might be a lumbrokinase used to dissolve blood clots. Earthworm gut microbial communities, with the traditional approaches and with the theoretical modeling of evolutionary strategies may helpful to develop a strategic approach that might lead to the technological up-gradation of bioremediation, to the medicinal important discoveries and to the development of the evolutionary theory.

As nature has its ways of resolving imbalances in environment and clean-up contaminated soils/lands using microbes, plants and earthworms. Both earthworms and microbes represent an important portion of soil biomass. Undoubtedly, they are key organism in bioremediation technology, modifying soil nutrients, microbial dynamics and to develop soft bioengineering tools to clean-up environment with long history of uses. Earthworm gut is richest source of microbes (yeast, bacteria, algae, diatoms and actinomycetes) that have potential to use as 'ecofriendly nano factories' for bioremediation process. Microbes are adapted to thrive in 'adverse conditions' of high acidity, alklanity, toxicity live together in consortium, interacting with gut of earthworms in various ways, depending on surrounding environment and ecological niches of inhabiting various species of worms. The survival of microbes in gut of earthworms may depend on their capacity to resist digestive enzymes of microbial or earthworm origin, intestinal mucus, $\mathrm{CaCo} 3$ to bacteriostatic and microbial substance and also, to transit time. Microbiomes of earthworm'gut especially culture-independent still not explored. It has been estimated approximately $99 \%$ of environmental microbes are non-culturable by currently available techniques. These large sections of uncultured microbes of earthworms' gut are untrapped reservoirs of novel biomolecules such as enzymes, drugs, as well as metabolic capabilities.

Metagenomic exploration of these poorly evaluated uncultured microbes of earthworms' gut might lead to provide genetic information on potentially novel biocatalysts or enzymes, genetic linkages between their function and structure. The study may helpful to boost the development of improved strategies for monitoring the impact of pollutants on ecosystems for clean up contaminated environments and to understand of how microbial communities of earthworms'gut cope with pollutants.

\subsection{Conclusions}

The comparison of study of different lineages of the model species Identification and screening of metagenome from earthworms inhabiting on different reactors of earthworms'gut may be crucial to study multiple case studies of biodegradation process of earthworms. That also indicates that the microbiota is a key player in Oligochaeta evolution. Comprehensive picture of micro-biota of earthworm presented in the study may improve our understanding of biodegradation process through activities of earthworms in future.

\subsection{Acknowledgement}

We acknowledge the financial support of the Department of Biotechnology, Ministry of Science and Technology, Govt. of India, New Delhi, to carry out this study.

\subsection{References}

1) Edwards C.A. and Bohlen P.J., 1996. Biology and ecology of earthworms ( $3^{\text {rd }}$ edition).Chapman \& Hall, London p. 426.

2) Gupta Shruti, Kushwah, Tanuja and Yadav Shweta, 2015 Exposure to ZnO-NPs enhanced gut- associated microbial activity in Eisenia fetida Journal of Toxicology and Environmental Health Sciences7(2), pp. 9-17, DOI: 10.5897/JTEHS2015.0330

3) Gupta. S., Kushwah. T. and Yadav. S., 2014. Earthworm coelomocytes as a nanoscavanger to ZnO-NPs. Nanoscale Research Letters 9:259.

4) Jinek M., Chylinski K., Fonfara I., Hauer M.,Dounda JS,Charpentier E.,2012. A programmable dual RNA-guided DNA endonucleases in adaptive bacterial immunity. Science 17:816-821.

5) Sinha R.K.,Agrawal Sunita, Chauhan Krunal Chauhan and Valani Dalsukh, 2010.The wonders of earthworms \&its vermicompost to farm production:Charles Darwin's friends of farmers'. with potential to replace destructive chemical fertilizers. Agricultural Sciences 1:76-94.

6) Stürzenbaum S.R., Georgiev O., Morgan A.J. and Kille P., 2004. Cadmium detoxification in earthworms: From genes to cells. Environ. Sci. Technol. 38:6283-6289. 